\title{
The Involvement of Malay Adolescents in Crime: Research on Residents of Asrama Akhlak Rusila, Marang
}

\author{
Sharifah Shahida Syed Muhsin, Nurul Jannah Mohd Juaini
}

\begin{abstract}
This study was conducted to investigate the historical background of Malay adolescents involved in juvenile criminal cases. The main purpose of this study is to identify the influences that have driven these Malay adolescents into crime. This study examines cases from a historical point of view to gather, comprehensively, more accurate information about the influences that have driven them into juvenile criminal cases. Hence, this study was conducted by using a qualitative approach. The author utilised intensive interview techniques among the selected respondents. For this study, 12 respondents were interviewed among the selected juvenile offenders at the Asrama Akhlak Rusila, Marang, Terengganu. The respondents were divided into three groups according to their family's socioeconomic background namely well-to-do family, moderate income family, and poor family based on official standards. The respondents are all male. The results of this study show that there are two major crimes being carried out by the Malay adolescents, namely drug abuse and theft. This study shows that there are three major factors that have driven the Malay adolescents to become involved in juvenile criminal cases, including the desire to try, being influenced by peer groups, and having problems in the family. Among these factors, it is found that the desire to try and being influenced by peer groups are the major causes driving the Malay adolescents into crime.
\end{abstract}

Index Terms - Asrama Akhlak Rusila, Marang, Terengganu, juvenile criminal cases, Malay adolescents, social work.

\section{INTRODUCTION}

Juveniles, aged 18 years and below, are very susceptible to involvement in drugs [1]. At the stage of adolescence, an individual goes through rapid changes physically, emotionally and socially. As a result of this, adolescents are usually emotionally unstable and facing various "problems".

Teenagers are an important group for the development of the country in the future. They are the future leaders that will empower the nation to build a Malaysia that is advanced, modern, harmonious, and tolerant, as well as have integrity.

Mental health and substance abuse issues are overrepresented in the juvenile justice population [2], [3] list mental health issues as a risk factor for delinquency, whereas others have found substance abuse [4] and drug use [5] to be predictive of recidivism. Screenings of juveniles entering an institution allow identification of mental health and substance abuse issues. If such issues are effectively

Revised Manuscript Received on July 10, 2019.

Sharifah Shahida Syed Muhsin, Faculty of Applied Social Sciences, Universiti Sultan Zainal Abidin, Gong Badak Campus, 21300 Kuala Nerus, Terengganu, Malaysia.

Nurul Jannah Mohd Juaini, Faculty of Applied Social Sciences, Universiti Sultan Zainal Abidin, Gong Badak Campus, 21300 Kuala Nerus, Terengganu, Malaysia. addressed by the institution, juveniles may be better able to participate in educational activities as they are treated and be able to better reintegrate into the community upon release. Since the provision of mental health services and substance abuse treatment leads to reductions in recidivism [6], [7], continuing to address these issues is of critical importance to the juvenile justice system.

The U.S. juvenile court and justice system has stood for reform and system improvement from its start [8]. First formalized in Illinois in 1899, juvenile court evolved from a variety of systems used to handle juvenile justice and child welfare matters during the nineteenth century and earlier [9]. During the same period, social norms in the United States were shifting, driven by large waves of immigration and urbanization.

Substance use among adolescents in the United States is a major public health problem and priority [10]. According to the 2013 Monitoring the Future study, approximately 28\% of American adolescents reported having used illicit substances during the year and approximately $36 \%$ of high school seniors stated they had used an illicit substance within their lifetimes [11].

Incarcerated adolescents are especially at risk for problems related to substance use. When compared to nonincarcerated youth, incarcerated adolescents reported high levels of substance use [12], [13]. Juvenile drug use may also be predictive of criminality continuing into adulthood. One study found that adults who had committed 90 or more offenses during the courses of their lifetimes were more likely to have used drugs as juveniles [14].

In 2011, male juvenile offenders accounted for $72 \%$ of delinquency arrests [15]. Property crimes were responsible for the highest numbers of arrests for both female (38\%) and male (36\%) juvenile offenders. Fortunately, there has been a gradual decline in the number of juvenile arrests. Between 1997 and 2011, there was a 38\% decline in male arrests and a $22 \%$ decline in female arrests [15].

In 2011, nearly 69,000 juveniles were being held in correctional or residential treatment facilities in the United States [16]. Approximately, $62 \%$ of juvenile offenders were placed in public correctional or residential treatment facilities, while $27 \%$ were placed in private facilities. This population of incarcerated adolescents included a spectrum

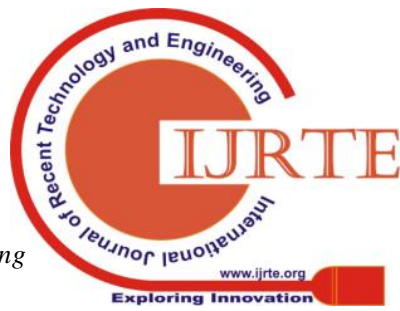


of races and ethnicities: Black (41\%), White (33\%), Hispanic (23\%), American Indian (2\%), and Asian/Pacific Islander (1\%) [17].

The parents' role is important in education their children. There are instances where parents do not concern themselves regarding their children's religious education. Thus, the child's life begins without proper religious guidance, causing them to become prone to falling into social ills.

\section{PROBLEM STATEMENT AND RESEARCH OBJECTIVE}

There are many factors that are associated with the involvement of adolescents in crime. There have been studies conducted that proved that factors such as self, peer influence and family institution are the main reasons adolescents get involved in juvenile crime.

\section{METHODOLOGY}

Methodology used is in this study is a qualitative method where the researcher conducted interviews with 12 respondents, made up of the juvenile offenders themselves, and two officers from Asrama Akhlak Rusila. Apart from this, the researcher also used the exploration method i.e. observing their way of life and daily activities at Asrama Akhlak Rusila, Marang. The researcher also studied how the adolescents became involved in juvenile crime.

In choosing informants, the technique used was by choosing informants from three different family backgrounds, i.e. four informants from well-to-do families, four informants from moderate income families and four informants from poor families.

This study is a characteristic of exploration [18]. Secondly, this study aims to present the current picture of the reality of juvenile crime involvement among Marang, Terengganu youths [19]. Moreover, this study will also explain the correlation between factors or variables measured [18]. Hence, it contains explanatory features for this study [20].

As a whole, this study is basically qualitative, it corresponds to the features described above [21]. Furthermore, the design of this study is used to achieve the objective of the study and to answer the questionnaire. Also, the study was conducted theoretically through phenomena and qualitative studies using phenomenology [22].

Managing this face-to-face interview is able to explain something that is unclear and can extract information directly from the informant, thus facilitating the collaboration between interviewers and informants [23].

Interview methods can overcome data collection problems that do not meet the purpose of the study. This is because the informants still have the opportunity to give their own choice and evaluation answers through this unstructured interview method [24]. Which, this answer can help to complete the question of the interview by the interviewer [25].
Selection of this method is very important based on the three criteria. First, this unstructured interview method can produce qualitative data [26]. Where, the question is openly asked to this informant to get the conversation in depth [27]. Secondly, the questions raised are more flexible and may vary according to the interview or response situation provided by informants [28]. Third, variation responses, the information that can be extracted through the answers can be diversified [29].

In addition to the above primary sources, the collection of secondary data is intended to achieve the objectives of the first study. The primary sources of secondary data used in this study are from articles, journals, dissertations, annual reports, and related texts [30].

Comparative analysis methods are continuously used to analyze qualitative research data as suggested by [31]. This method of analysis is accurately used in this study to obtain phenomenological results [32]. This method also provides trust and confidentiality to researchers and informants in analyzing study information [33].

This study uses descriptive. This method aligns with the research objective and problem statement. Six main research processes were included to complete this study. This chapter/section explains the methodology, techniques and methods used in this study.

The following were done for the completion of this study:

1) The research framework was created for the overall study

2) The sampling method and main research that will become the main source of information for the study outcome were chosen

3) The instruments to extract the information from the source of this study was chosen

4) The method for collecting data was determined

5) The procedure for the overall research was determined

6) The method for data analysis to get the research results was identified.

\section{RESULTS AND DISCUSSION}

The method used for data analysis was by using continuous comparison. The analysis was divided into two main sections. The first section was an analysis of the interviews conducted with the juvenile adolescents. This section was divided further into five sub-sections for analysis. These sub-sections included the informant demography, the relation of the informant with social support, the effects of social support towards crime, the informant rehabilitation process, and future direction of the informants. The second section of the analysis was the outcome from the interviews with the officers. For this section, analysis focused on the officers' observation and their elaboration on the informants. Results from both sections were then synthesised together to achieve data that were deemed as having reliability.

\section{A. Informant Demography}


Table 1: Informant demography

\begin{tabular}{|c|c|c|c|c|c|c|}
\hline Informant & Age & $\begin{array}{c}\text { Place } \\
\text { of Birth }\end{array}$ & $\begin{array}{c}\text { Number of } \\
\text { Siblings }\end{array}$ & $\begin{array}{c}\text { Father's } \\
\text { Occupation }\end{array}$ & $\begin{array}{c}\text { Mother's } \\
\text { Occupation } \\
\end{array}$ & $\begin{array}{c}\text { Education } \\
\text { Level }\end{array}$ \\
\hline Informant 1 & 17 & Terengganu & 4 & Teacher & Administrative assistant & PMR \\
\hline Informant 2 & 17 & Terengganu & 5 & General assistant & Customer service assistant & PMR \\
\hline Informant 3 & 17 & Kelantan & 7 & Military retiree & Self-employed (small business) & UPSR \\
\hline Informant 4 & 17 & Kelantan & 4 & No fixed employment & Factory operator & UPSR \\
\hline Informant 5 & 17 & Terengganu & 12 & Unemployed & Assistant at eatery & PMR \\
\hline Informant 6 & 14 & Kelantan & 4 & Newspaper delivery boy & (Passed away) & UPSR \\
\hline Informant 7 & 16 & Kelantan & 8 & Mechanic & Assistant at petrol station & UPSR \\
\hline Informant 8 & 17 & Terengganu & 8 & Construction worker & (Passed away) & UPSR \\
\hline Informant 9 & 16 & Terengganu & 3 & $\begin{array}{c}\text { Factory security } \\
\text { personnel }\end{array}$ & Unemployed & UPSR \\
\hline $\begin{array}{c}\text { Informant } \\
10 \\
\end{array}$ & 14 & Terengganu & 3 & Information unavailable & Unemployed & UPSR \\
\hline $\begin{array}{c}\text { Informant } \\
11 \\
\end{array}$ & 17 & Terengganu & 10 & Construction worker & Unemployed & None \\
\hline $\begin{array}{c}\text { Informant } \\
12 \\
\end{array}$ & 17 & Kelantan & 5 & Recyclable item collector & Unemployed & UPSR \\
\hline
\end{tabular}

Referring to Table 1, overall the place of birth of informants are localized to areas in the east coast, where the population is mostly made up of Malays and Muslims. However, adolescents here are susceptible still to juvenile problems. The majority of the informants are 17 years of age, with only two informants at 14 years and two informants at 16 years. From this data acquired, it can be shown that the ages between 14 and 17 are the peak of when crime is committed among adolescents. The number of family members is also a factor that plays a significant role in determining the involvement of adolescents in juvenile crime. Overall, the informants involved in crime come from big families, of five to 12 people per family. As a result of this large family, the parents were unable to give full attention to their children, leading to the informant becoming involved in juvenile crime.

If seen from the parents' occupations, nearly all of them work in non-professional fields. Only one informant's father has professional employment, as a teacher. With this, it can be seen that the parents are not highly educated. It is generally known that the parents' education level plays a part in educating the children. The parents' occupations are also significant in determining the life of the children. From data collected, six of eight fathers of the informants do not have fixed employment. Three mothers do not have fixed employment and two have passed away. It can be summarized that the informants" families have constant struggles in continuing life. This has caused attention and guidance for the informants to not be adequately given.
The education level of most informants is also mostly at the UPSR (Ujian Pencapaian Sekolah Rendah) level. This shows that their education level is at a minimum and their way of thinking is still yet to mature. This also shows that the informants have shown a lack of interest in education since their primary school years. As such, the informants have been more inclined to get involved in social ills such as truancy, loitering and promiscuity, causing them to commit juvenile offences. From results acquired, it can be seen the informants begin committing offences since primary school, i.e. at around 12 years old.

Based on the above discussion, it can be summarized that the informants' inclination to commit juvenile crimes began in primary school. Among the early factors causing this include having a large family, lack of attention from the informants' parents, and the informants still yet to reach maturity. Thus, this study recommends that these factors should be given extra focus in the development of adolescents.

\section{B. Relations between Informant and Social Support System}

There were four main questions put forth to the 12 informants. Among them included: "How was the informant's interactions during primary school?", How was the informant's interactions during secondary school?", "How was the informant's interactions with neighbours?", and "How was the informant's interactions with siblings?". Feedback received from the informants were discussed to obtain a clearer picture on how the factor of social support relations contributed to the informant becoming involved in juvenile crimes. 
THE INVOLVEMENT OF MALAY ADOLESCENTS IN CRIME: RESEARCH ON RESIDENTS OF ASRAMA AKHLAK RUSILA, MARANG

Table 2: Relations between informant and social support system

\begin{tabular}{|c|c|c|c|c|}
\hline \multirow[b]{2}{*}{ Informant } & \multicolumn{4}{|c|}{ Relations with Social Support System } \\
\hline & At Primary School & At Secondary School & With Neighbours & With Siblings \\
\hline Informant 1 & Good & Good & Does not interact & Good \\
\hline Informant 2 & Good & $\begin{array}{c}\text { Good with peers, less interaction with } \\
\text { teachers }\end{array}$ & $\begin{array}{l}\text { Interacts with } \\
\text { neighbours }\end{array}$ & Good \\
\hline Informant 3 & $\begin{array}{l}\text { Good, has good } \\
\text { relations with } \\
\text { teachers }\end{array}$ & Good & $\begin{array}{l}\text { Less interaction } \\
\text { with neighbours }\end{array}$ & $\begin{array}{l}\text { Not good, has } \\
\text { problems among } \\
\text { siblings }\end{array}$ \\
\hline Informant 4 & Good & Good & Good & $\begin{array}{l}\text { Not good, has a } \\
\text { brother who is a drug } \\
\text { addict }\end{array}$ \\
\hline Informant 5 & Good & Does not attend school, has no friends & Does not interact & Good \\
\hline Informant 6 & Good & Does not attend school & Good & Good \\
\hline Informant 7 & Good & $\begin{array}{l}\text { Not good, has many older and same- } \\
\text { aged friends }\end{array}$ & $\begin{array}{l}\text { Not good, } \\
\text { always at odds } \\
\text { with neighbours }\end{array}$ & Good \\
\hline Informant 8 & Good & $\begin{array}{l}\text { Not good, many peers becoming drug } \\
\text { addicts }\end{array}$ & $\begin{array}{l}\text { Some good and } \\
\text { some bad }\end{array}$ & $\begin{array}{l}\text { Not good, more of a } \\
\text { loner }\end{array}$ \\
\hline Informant 8 & Good & $\begin{array}{l}\text { Not good, many peers becoming drug } \\
\text { addicts }\end{array}$ & $\begin{array}{c}\text { Some good and } \\
\text { some bad }\end{array}$ & $\begin{array}{l}\text { Not good, more of a } \\
\text { loner }\end{array}$ \\
\hline Informant 9 & Good & Does not attend school & Good & $\begin{array}{l}\text { Not good, likes to } \\
\text { walk late at night }\end{array}$ \\
\hline Informant 10 & Good & $\begin{array}{c}\text { Registered but does not attend school. } \\
\text { No vehicle available and mother does } \\
\text { not allow staying in hostel }\end{array}$ & Good & Good \\
\hline Informant 11 & Good & Does not attend school & Good & $\begin{array}{l}\text { Strong bond with } \\
\text { siblings }\end{array}$ \\
\hline Informant 12 & $\begin{array}{l}\text { Good, but has had } \\
\text { fights with friends }\end{array}$ & Good & Good & Good \\
\hline
\end{tabular}

Table 2 shows the informants' relations with four social support institutions, i.e. primary school, secondary school, local community and family. Based on the results acquired, all 12 informants said they had good relations with friends and teachers in primary school. Only one informant mentioned that there were problems with peers, leading to having had fights at school.

Secondly, during secondary school, there were mixed responses from informants. Only five of the 12 informants had good relations at secondary school. One informant gave a different response, but overall still had good relations with everyone.

Five informants stated that they did not or did not continue schooling at secondary school level. However, two informants provided extra information on why they were not schooling. The remaining informants stated that they did not have good relations during secondary school.

If the informants' responses are examined carefully, informants 5 and 10 stated that peer influence and family were factors behind them not attending school. This is significant and needs to be investigated as it has direct relation to the informant. Thus, these factors have a huge impact on the informant's decision-making. Informants 7 and stated that they had problems at school, due to peer influence and their surroundings. Their friends were of bad influence, especially in the case of informant 8 , whose friend influenced him into drug abuse. Being exposed to such negative surroundings, informants 7 and 8 were often involved in disciplinary issues while in school, causing their relations with the community to weaken.

Third to be discussed is the relationship between the informant and their community. Overall, a majority of informants have good relations and do not have problems with their neighbours. Only two informants stated that they had bad relations with their neighbours. With the surrounding community having a bad perspective of the adolescents, relations between the former and the latter became unharmonious. This is even though it is generally understood that the teenage years are the peak times for the development of an adolescent's emotions and personality. Therefore, care from the community is important especially in the form of positive affirmations and constructive criticism.

Juvenile delinquents who have been released from incarceration in Massachusetts are more likely to reoffend due to issues related to availability of schooling, and less likely to reoffend due to availability of prosocial activities. Their neighborhood risks are vital to the understanding of youth recidivism rates. A successful reintegration of youth poses numerous benefits to the individual and to society [34]. 
Lastly are the relations between the informants and their families, i.e. parents and siblings. Eight informants stated that they have good relations with their family. Four other informants stated otherwise. Most informants stated that they had no problems with their parents, even though some parents were divorced or were with single parents (having their mother pass away). However, these informants do not have very good relations with their siblings (brother or sister). This caused them to go through emotional stress. With this, the informants sought other ways to relieve of their stress such as staying out late at night, drug abuse, staying in isolation in their own room, etc. These informants were then inclined to commit juvenile crimes to get a form of satisfaction in life.

\section{Effects of Social Support towards Juvenile Crime}

Based on the above information, this section further investigates the effects of social support systems on adolescents. This section will also examine and identify the types of offences, locations the offences were committed, and causal factors for the informant to commit juvenile crimes.

Table 3: Effects of social support towards juvenile crime

\begin{tabular}{|c|c|c|c|}
\hline \multirow[t]{2}{*}{ Informant } & \multicolumn{3}{|c|}{ Effects } \\
\hline & Type of Offense & Cause & Location \\
\hline Informant 1 & $\begin{array}{l}\text { Stealing manhole covers } \\
\text { four years ago }\end{array}$ & $\begin{array}{l}\text { Influence of drugs, wanting } \\
\text { to try }\end{array}$ & Nearby village, Pulau Rusa, Terengganu \\
\hline Informant 2 & Dealing drugs since Form 1 & Peer influence & Around villages in Kuala Nerus, Terengganu \\
\hline Informant 3 & Stealing motorcycles & $\begin{array}{c}\text { Peer influence and stress } \\
\text { due to family issues }\end{array}$ & $\begin{array}{c}\text { Around villages, throughout the state of } \\
\text { Kelantan }\end{array}$ \\
\hline Informant 4 & $\begin{array}{l}\text { Dealing drugs and drug } \\
\text { abuse }\end{array}$ & Peer influence & $\begin{array}{l}\text { In city and village areas, Tanah Merah, } \\
\text { Kelantan }\end{array}$ \\
\hline Informant 5 & Drug abuse & Peer influence & In the suburbs of Cendering, Terengganu \\
\hline Informant 6 & Stole a mobile phone & Own self & Cybercafe in Kuala Krai, Kelantan \\
\hline Informant 7 & Stealing of telephone cables & Own self & In village in Kota Bharu \\
\hline Informant 8 & Stealing motorcycles & For money and due to peer & $\begin{array}{c}\text { In villages throughout the state of } \\
\text { Terengganu }\end{array}$ \\
\hline Informant 9 & Drug abuse & Peer pressure & In the village of Batu Rakit, Terengganu \\
\hline Informant 10 & Stole a motorcycle & Family influence (brother) & In village areas, Dungun, Terengganu \\
\hline Informant 11 & Possession of drugs & Peer influence and own self & In village areas, Telemong, Terengganu \\
\hline Informant 12 & Drug abuse & Peer influence and own self & In village areas, Tumpat, Kelantan \\
\hline
\end{tabular}

The biggest composition of the type of crimes committed by the informants is theft, committed by six informants. Of the remaining informants, four were into drug abuse and two for drug dealing. Eight informants stated that they committed the crimes due to peer influence. Peer influence has a big impact on informants, up to $66.7 \%$ compared to influence from siblings or drugs and money. Their own self also is a factor in their inclination in committing crimes, to which six informants admitted to. However, even more surprising in the results is that the crimes were mostly committed in village areas compared to city areas. Thus, it can be said that village areas are more prone to crimes such as theft and drug abuse among adolescents.

The factor of peer influence shows a significant relationship with the inclination of adolescents becoming involved in juvenile crimes. This means that peer influence is an important factor driving someone to commit an act.
From the results of this study, it is found that the factor of one's own self, such as having emotional stress, is a main cause of adolescents becoming involved in juvenile crime, especially drug abuse. Emotional stress in this study refers to the emotional state of being confused, angry, disappointed, sad, depressed, and bored. Unconsciously, these problems can drive adolescents into social ills and juvenile crime.

\section{Informant Rehabilitation Process}

This section will analyse responses from the informants. Four main items will be looked at in this analysis. These include: 1) the informant's duration of stay at the hostel; 2) the informant's feelings at the hostel; 3) the activities carried out at the hostel; and 4) the informant's relations with others at the hostel. These results will then determine whether the rehabilitation process is going well and determine the factors that will help this process. 
THE INVOLVEMENT OF MALAY ADOLESCENTS IN CRIME: RESEARCH ON RESIDENTS OF ASRAMA AKHLAK RUSILA, MARANG

Table 4: Informant rehabilitation process

\begin{tabular}{|c|c|c|c|c|}
\hline \multirow[t]{2}{*}{ Informant } & \multicolumn{4}{|c|}{ Rehabilitation Process } \\
\hline & Duration & Current Feelings & Current Activities & Interaction in Hostel \\
\hline Informant 1 & 12 months & Happy and independent & $\begin{array}{l}\text { Working in the kitchen, } \\
\text { cooking }\end{array}$ & $\begin{array}{l}\text { Good, matured, no } \\
\text { bullying }\end{array}$ \\
\hline Informant 2 & 10 months & $\begin{array}{l}\text { Happy, regretful and learning } \\
\text { to take care of self }\end{array}$ & Religious activities & Good \\
\hline Informant 3 & 9 months & Happy & Marching and sports & Good \\
\hline Informant 4 & 3 months & Happy & Gardening & Good \\
\hline Informant 5 & 1 months & Good, homesick & Washing bed cloths & Good \\
\hline Informant 6 & 5 months & Happy & Workshop activities & Good \\
\hline Informant 7 & 1 year 5 months & Happy & $\begin{array}{l}\text { Reciting the Quran, member } \\
\text { of the Quran reciting club }\end{array}$ & Good \\
\hline Informant 8 & 2 months & $\begin{array}{l}\text { Unhappy, cannot interact } \\
\text { with peers }\end{array}$ & Normal activities & Normal \\
\hline Informant 9 & 5 months & Normal & Normal activities & Good \\
\hline Informant 10 & Less than a month & Normal, homesick & Normal activities & Good \\
\hline Informant 11 & Unknown & Happy & Normal activities & Good \\
\hline Informant 12 & 10 months & Happy & $\begin{array}{l}\text { Cleaning, workshop } \\
\text { activities, reciting the Quran }\end{array}$ & uncomfortable \\
\hline
\end{tabular}

\section{E. Future Direction of Informant}

The last question put forth to the informants was regarding their future direction. Through their responses, we can see the informants' vision for when they leave the hostel. These results will also show the effects of the rehabilitation process and early information on how the informants have changed to become better, and in turn be responsible towards their family, their community and the country.

Table 5: Informants' future direction

\begin{tabular}{|c|c|c|}
\hline \multirow{2}{*}{ Informant } & Hopes & Future Direction \\
\cline { 2 - 3 } & To become successful & Does not want to enter rehabilitation again \\
\hline Informant 1 & To change and become a better person & $\begin{array}{c}\text { Find a place to stay away from the village and find } \\
\text { employment }\end{array}$ \\
\hline Informant 2 & To remove tattoos & Find employment \\
\hline Informant 3 & To take care of parents & Stay with mother and find employment \\
\hline Informant 4 & Does not want to enter rehabilitation again & Stay with sister and find employment \\
\hline Informant 5 & None & Resume studies \\
\hline Informant 6 & To help parents & Find employment \\
\hline Informant 7 & Wants to change & Find employment \\
\hline Informant 8 & To become successful & Resume studies \\
\hline Informant 9 & To help mother in Johor & Resume studies \\
\hline Informant 10 & Wants to learn how to do business & Find employment \\
\hline Informant 11 & To & \\
\hline Informant 12 & &
\end{tabular}

Referring to Table 5, there are two main responses. The first is to change for the better or being regretful of their past offences. This response was given by four informants. The other response was that they wanted to help their parents when they finally leave the hostel. The remaining informants wanted to go into business, become successful or remove their tattoos. Even so, in general, the informants hope to have a good life and change to become better.

Therefore, to change for the better, they need a good plan for themselves. Eight informants plan to seek employment when they leave the hostel. Three more informants plan to resume their studies while the remaining informants stated that they did not want to enter rehabilitation again.
In conclusion, the informants want to have become more responsible, become better and contribute to their community and the country. This can be seen from their responses in the results, such as wanting to help their parents. Based on this response, it is clear that the informants want to become more responsible for their family. The other common response was that they want to seek employment in the future. This shows they would like to give back to their community and the country. 


\section{CONCLUSION}

In conclusion, this study provides exposure to the involvement of Malay adolescents in juvenile criminal cases. This study also suggests that all parties take responsibility in raising awareness among teenagers of the negative effects of being involved in criminal cases, to raise a better and visionary generation.

Therefore, to avoid adolescents from becoming involved in juvenile criminal cases, all parties must play their roles, including school counselors, family members, and members of the community. Encouragement and life guidance from loved ones and the surrounding community can avoid teenagers from trying out acts without knowing their consequences. With supervision from family and the community, teenagers can avoid getting involved in social ills that can affect their future. Further study using more comprehensive data combining interview results and observation on the informants needs to be conducted by future researchers.

Family members play an important in handling juvenile crime. Parents need to educate and supervise their children's activities. Parents also need to supervise their children's mobile phone usage, to avoid their children being influenced by negative activities from the internet.

Support from the surrounding community is also an important element. Many studies find that communities are still hesitant in accepting juvenile offenders that have finished their sentences. This indirectly causes the adolescents to return to their old ways.

The school authorities must also give attention to prevention programmes as school children are very susceptible to various issues due to lack of knowledge and experience. Results from this study can be used as a basis to prove to school children that they have to be careful, especially when having emotional stress. This factor should to be stressed for those who have already been involved in disciplinary problems such as truancy and smoking. This is to avoid them from going into even bigger criminal offences such as drug abuse and drug dealing. Lastly, it is hoped that this study will help the efforts by Jabatan Kemajuan Masyarakat to rehabilitate juvenile offenders and turning them into better people that can contribute to their family, their surrounding community and the country.

\section{ACKNOWLEDGMENT}

The author would like to thank KPT for providing financial support for this research. Special thanks are also dedicated to Universiti Sultan Zainal Abidin (UNISZA).

\section{REFERENCES}

1. Law of Malaysia, Act 611: Child Act 2001. Available: http://www.agc.gov.my/agcportal/uploads/files/Publication s/LOM/EN/Act\%20611.pdf.

2. J. D. Burke, E. P. Mulvey, and C. A. Schubert, "Prevalence of mental health problems and service use among first-time offenders," Journal of Child and Family Studies, 24, 2015,

3. M. W. Lipsey, J. C. Howell, M. R. Kelly, G. Chapman, and D. Carver, "Improving the effectiveness of juvenile justice pp. 3774-3781.

programs: A new perspective on evidence-based practice. Washington DC: Georgetown University, 2010.

4. C. C. Cottle, R. J. Lee, and K. Heilbrun, "The prediction of criminal recidivism in juveniles: A metaanalysis," Criminal Justice and Behavior, 28(3), 2001, pp. 367-394.

5. M. Staton-Tindall, K. L. H. Harp, E. Winston, J. M. Webster, and K. Pangburn, "Factors associated with recidivism among corrections-based treatment participants in rural and urban areas," Journal of Substance Abuse Treatment, 56(1), 2015, pp. 16-22.

6. N. D. Volkow, An examination of drug treatment programs needed to ensure successful re-entry. Available: https://archives.drugabuse.gov/testimonies/2006/examinati on-drug-treatment-programs-needed-to-ensure-successfulre-entry.

7. M. L. Hiller, K. Knight, and D. D. Simpson, "Prison-based substance abuse treatment, residential aftercare and recidivism," Addiction, 94(6), 2002, pp. 833-842.

8. R. Jesse, and M. Ein, "Achieving juvenile justice reforms through decision-making structures: The care of Georgia," Journal of Juvenile Justice, 6(7), 2017, pp. 98-111.

9. S. J. Fox, "The early history of the court," The Juvenile Court, 6(3), 1996, pp. 29-39.

10. W. Michael, R. Timothy, H. James, A. Joseph, and J. Morris, "Substance use services for adolescents in juvenile correctional facilities," A National Study, 4(2), 2015, pp. 13-14.

11. L. D. Johnston, R. A. Miech, P. M. O'Malley, J. G. Bachman, J. E. Schulenberg, and M. E. Patrick, Monitoring the future national survey results on drug use 1975-2017: Overview, key findings on adolescent drug use. Available: https://deepblue.lib.umich.edu/bitstream/handle/2027.42/1 48123/Overview\%202018\%20FINAL\%20print\%20130.pdf? sequence $=1 \&$ is Allowed $=\mathrm{y}$.

12. J. J. Wilson, N. Rojas, R. Haapanen, E. Duxbury, and H. Steiner, "Substance abuse and criminal recidivism: A prospective study of adolescents," Child Psychiatry and Human Development, 31(4), 2001, pp. 297-312.

13. J. D. Ford, J. K. Hartman, J. Hawke, and J. F. Chapman, "Traumatic victimization, posttraumatic stress disorder, suicidal ideation, and substance abuse risk among juvenile justice-involved youth," Journal of Child and Adolescent Trauma, 1(1), 2008, pp. 75-92.

14. M. DeLisi, A. Angton, M. P. Behnken, and A. M. Kusow, "Do adolescent drug users fare the worst? Onset type, juvenile delinquency, and criminal careers," International Journal of Offender Therapy and Comparative Criminology, 20(10), 2013, 1-16.

15. S. Hockenberry, and C. Puzzanchera, Juvenile court statistics 2011. Available: http://ojjdp.gov/ojstatbb/njcda/pdf/jcs2011.pdf.

16. Office of Juvenile Justice and Delinquency Prevention, OJJDP statistical briefing book. Available: https://www.ojjdp.gov/ojstatbb/.

17. M. Sickmund, T. J. Sladky, and W. Kang, Easy access to the census of juveniles in residential placement. Available: http://www.ojjdp.gov/ojstatbb/ezacjrp/.

18. J. W. Creswell, and J. D. Creswell, Research Design: Qualitative, Quantitative, and Mixed Methods Approaches. California: Sage Publications, 2017.

19. P. Eriksson, and A. Kovalainen, Qualitative Methods in Business Research: A Practical Guide to Social Research. California: Sage Publications, 2015.

20. S. J. Taylor, R. Bogdan, and M. DeVault, Introduction to Qualitative Research Methods: A Guidebook and Resource. New Jersey: John Wiley and Sons, 2015. 
21. S. Lewis, "Qualitative inquiry and research design: Choosing among five approaches," Health Promotion Practice, 16(4), 2015, pp. 473-475.

22. E. Leibenluft, D. S. Charney, K. E. Towbin, R. K. Bhangoo, and D. S. Pine, "Defining clinical phenotypes of juvenile mania," American Journal of Psychiatry, 160(3), 2003, pp. 430-437.

23. U. Sekaran, and R. Bougie, Research Methods for Business: A Skill Building Approach. New Jersey: John Wiley and Sons, 2016.

24. M. Sabitha, Kaedah Penyelidikan Sains Sosial. Selangor: Prentice Hall, 2005.

25. M. Q. Patton, Qualitative Research. New Jersey: John Wiley and Sons, 2005.

26. D. K. Padgett, Qualitative Methods in Social Work Research. California: Sage Publications, 2016.

27. V. Minichiello, R. Aroni, and T. Hays, In-Depth Interviewing: Principles, Techniques, Analysis. Queensland: Pearson Education, 2008.

28. S. Cormier, P. S. Nurius, and C. J. Osborn, Interviewing and Change Strategies for Helpers. Boston: Cengage Learning, 2016.

29. I. Seidman, Interviewing as Qualitative Research: A Guide for Researchers in Education and the Social Sciences. New York: Teachers College Press, 2013.

30. A. Bryman, and E. Bell, Business Research Methods. New York: Oxford University Press, 2015.

31. B. G. Glaser, and A. L. Strauss, Discovery of Grounded Theory: Strategies for Qualitative Research. New York: Routledge, 2017.

32. B. Holmes, Comparative Education: Some Considerations of Method. London: Routledge, 2018.

33. T. A. Schwandt, The Sage Dictionary of Qualitative Inquiry. California: Sage Publications, 2015.

34. L. A. Demeter, and S. Nokuthula, "Neighborhood risks and resources correlated with successful reentry of youth returning from Massachusetts detention centers," OJJDP Journal of Juvenile Justice, 6 (2), 2017, pp. 28-29. 